\title{
Pathobiology of Tennessee 2017 H7N9 low and high pathogenicity avian influenza viruses in commercial broiler breeders and specific pathogen free layer chickens
}

\author{
Kateri Bertran, Dong-Hun Lee, Miria F. Criado, Diane Smith, David E. Swayne and Mary J. Pantin-Jackwood ${ }^{*}$
}

\begin{abstract}
In March 2017, H7N9 highly pathogenic avian influenza (HPAl) virus was detected in 2 broiler breeder farms in the state of Tennessee, USA. Subsequent surveillance detected the low pathogenicity avian influenza (LPAI) virus precursor in multiple broiler breeder farms and backyard poultry in Tennessee and neighboring states. The pathogenesis of the H7N9 LPAI virus was investigated in commercial broiler breeders, the bird type mostly affected in this outbreak. Infectivity, transmissibility, and pathogenesis of the H7N9 HPAl and LPAI viruses were also studied in 4-week-old specific pathogen free (SPF) leghorn chickens. The mean bird infectious doses $\left(B_{1 D_{50}}\right)$ for the LPAl isolate was $5.6 \log _{10}$ mean egg infectious dose $\left(\mathrm{EID}_{50}\right)$ for broiler breeders and $4.3 \log _{10} \mathrm{EID}_{50}$ for SPF layer chickens, and no transmission to contact-exposed birds was observed. In both bird types, virus shedding was almost exclusively from the oropharyngeal route. These findings suggest sub-optimal adaptation for sustained transmission with the H7N9 LPAl isolate, indicating that factors other than the birds genetic background may explain the epidemiology of the outbreak. The $\mathrm{BID}_{50}$ for the HPAl isolate in SPF layer chickens was more than 2 logs lower $\left(<2 \log _{10} \mathrm{EID}_{50}\right)$ than the LPAl isolate. Also, the HPAI virus was shed by both the oropharyngeal and cloacal routes and transmitted to contacts. Greater susceptibility and easier transmission of the H7N9 HPAl virus are features of the HP phenotype that could favor the spread of HPAI over LPAI viruses during outbreaks.
\end{abstract}

\section{Introduction}

Waterfowl are the natural reservoirs of avian influenza (AI) virus and usually carry the low pathogenic (LP) phenotype [1-3]. Occasionally, LPAI viruses can transmit from wild birds to domestic poultry resulting in subclinical infections or mild respiratory disease and drops in egg production, although adverse conditions can predispose birds to a more severe disease [4]. After circulating in gallinaceous poultry, some H5 and H7 LPAI viruses can mutate to the highly pathogenic (HP) phenotype, causing severe systemic disease and high mortality in domestic birds [5]. The acquisition of multiple basic amino acids

\footnotetext{
*Correspondence: mary.pantin-jackwood@ars.usda.gov

Exotic and Emerging Avian Viral Diseases Research Unit, Southeast Poultry Research Laboratory, U.S. National Poultry Research Center, Agricultural Research Service, U.S. Department of Agriculture, 934 College Station Rd,
} Athens, GA 30605, USA

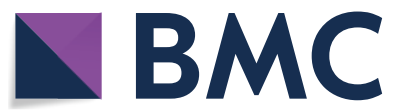
(c) The Author(s) 2018. This article is distributed under the terms of the Creative Commons Attribution 4.0 International License
(http://creativecommons.org/licenses/by/4.0/), which permits unrestricted use, distribution, and reproduction in any medium,
provided you give appropriate credit to the original author(s) and the source, provide a link to the Creative Commons license,
and indicate if changes were made. The Creative Commons Public Domain Dedication waiver (http://creativecommons.org/ publicdomain/zero/1.0/) applies to the data made available in this article, unless otherwise stated. at the cleavage site of the hemagglutinin (HA) via recombination, insertion, or mutations is a molecular determinant for high pathogenicity. Consequences of AI virus infection in poultry include negative economic impact on agriculture and a potential source for pandemic viruses in humans $[6,7]$.

In March 2017, concurrent outbreaks of H7N9 LPAI and HPAI virus were confirmed in broiler breeder flocks in the state of Tennessee, USA, with additional commercial broiler breeder flocks and mixed species in backyard flocks within the states of Alabama, Kentucky, and Georgia being affected with H7N9 LPAI virus $[8,9]$. Surveillance data and genetic analyses suggested multiple introductions of LPAI virus before mutation to high pathogenicity and inter-farm transmission [8]. Phylogenetic analyses based on complete genome sequences also showed that these viruses were closely related to 
a wild duck-origin H7N9 LPAI virus isolated 6 months previously in Wyoming [8]. The inserted sequences at the HA cleavage site (PENPKTDRKSRHRRIR/G, insertion sequence is underlined) in $\mathrm{H} 7$ viruses had $100 \%$ sequence homology to chicken $28 \mathrm{~S}$ rRNA, suggesting that the mutation occurred during virus replication in chickens [8]. Therefore, a LPAI virus was likely transmitted from wild aquatic birds to poultry and subsequently mutated to HPAI virus within one broiler breeder flock before spreading to a second broiler breeder flock within the control zone. Fortunately, the outbreak was effectively controlled in a timely fashion, with no further premises affected and no human infections identified.

Different genetic background between layer- and broiler-type chickens may have an effect not only on performance but also on genetic expression and immunological responses [10-12], accounting for differences in susceptibility to AI virus infection between both chicken types [13-20]. We recently showed that broilers, regardless of age, were less susceptible to H5N2 HPAI virus (Midwestern USA, 2015) than layers, but similarly susceptible to turkeys [21-23]. Since this H5N2 HPAI virus outbreak (Midwestern USA, 2015) affected commercial turkey and layer farms but not broiler farms [24], our findings suggested that genetic resistance of broilers to infection may have partially accounted for the lack of affected broiler premises, but other factors such as fewer outside-to-on-farm exposure to contacts, type of production management system, leaving broiler farms unpopulated in the control zone, or enhanced biosecurity, could have resulted in the lack of broiler farms being affected [21]. Different from recent HPAI virus outbreaks in poultry in the USA, i.e. H5N2 in Midwest and H7N8 in Indiana, which involved mostly turkeys and layers [24, 25], the Tennessee 2017 H7N9 AI virus outbreaks affected mainly broiler breeder commercial premises $[8,9]$. The absence of affected layer premises could be due to their low number in the affected region or failure to introduce a H7N9 virus onto the farms due to management factors [9].

Understanding breed-related differences in susceptibility to AI virus infections can help elucidate the complex pathobiology of AI and decisively impact optimal management of outbreak control strategies. In the present study, pathogenesis of the Tennessee 2017 H7N9 LPAI virus was investigated in commercial broiler breeders, the bird type mostly affected in this outbreak. In order to compare the infectivity, transmissibility, and pathogenicity of the Tennessee 2017 H7N9 LPAI and HPAI isolates with AI viruses from similar previous outbreaks, such as H7N8 HPAI virus (Indiana, 2016), we also studied the viruses in young SPF layer chickens.

\section{Materials and methods}

\section{Viruses}

Egg passage stocks of A/chicken/Tennessee/17-007431-3/2017 H7N9 LPAI virus (GenBank accession numbers KY818816-KY818823) and A/ chicken/Tennessee/17-007147-2/2017 H7N9 HPAI virus (GenBank accession numbers KY818809-KY818815) were provided by the National Veterinary Services Laboratories, Animal and Plant Health Inspection Service (APHIS), United States Department of Agriculture (USDA). The H7N9 LPAI and HPAI isolates differ by a 9-amino-acid insertion in the HA gene and 18 additional amino acids throughout the genome [8]. Working stocks were prepared (egg passage 1) and titrated in embryonating chickens eggs (ECE) using standard methods [26]. Stocks were diluted to the target dose with brain heart infusion (BHI) broth (Becton, Dickinson and Company, Sparks, MD, USA). The studies were performed in biosecurity level-3 enhanced (BSL-3E) facilities in accordance with procedures approved by the Institutional Biosafety Committee of the U.S. National Poultry Research Center (USNPRC), Agricultural Research Service (ARS), USDA.

\section{Animals and housing}

Cobb broiler breeders in lay were obtained from a commercial producer (courtesy of John Smith and Sarah Tilley, Fieldale Farms Corp., Baldwin, GA, USA). Specific pathogen free (SPF) White Leghorn chickens were obtained from the USNPRC in-house flocks. At 4 weeks of age (SPF layer chickens) or 36 weeks of age (broiler breeders), birds were transferred to animal BSL-3E facilities at the USNPRC for challenge. Representative number of each bird type was bled immediately prior to challenge to confirm the absence of AI virus antibody by hemagglutinin inhibition (HI) assays. Each experimental group was housed in self-contained isolation units ventilated under negative pressure with inlet and exhaust HEPA-filtered air. The birds had ad libitum access to feed and water. This study was reviewed and approved by the USNPRC Institutional Animal Care and Use Committee. Assessment of egg production in broiler breeders and virus contamination of eggs was not possible because housing in isolation cabinets prevented collection of eggs.

\section{Experimental design and sampling Infectivity and transmission}

To evaluate the mean bird infectious dose $\left(\mathrm{BID}_{50}\right)$ and lethal dose $\left(\mathrm{BLD}_{50}\right)$ of the viruses, birds were divided into groups as shown in Table 1 and individually tagged for identification. The inocula were prepared by diluting working virus stocks to approximately 2 (low dose), 4 (medium dose), or 6 (high dose) $\log _{10}$ mean egg infectious doses $\left(\mathrm{EID}_{50}\right)$ in $0.1 \mathrm{~mL}$ and were administered by 
Table 1 Infectivity, lethality, and transmission study design and summary results

\begin{tabular}{|c|c|c|c|c|c|c|c|}
\hline Bird type (age) & Challenge virus & Dose $\left(\log _{10}\right)$ & $\begin{array}{l}\text { Inoculated } \\
\text { infected/ } \\
\text { total }^{\mathrm{a}}\end{array}$ & $\mathrm{BID}_{50}\left(\log _{10}\right)$ & $\begin{array}{l}\text { Inoculated } \\
\text { dead/total } \\
\left(\mathrm{MDT}^{\mathrm{b}}\right)\end{array}$ & $B L D_{50}\left(\log _{10}\right)$ & $\begin{array}{l}\text { Contact- } \\
\text { exposed } \\
\text { infected/total }^{c}\end{array}$ \\
\hline \multirow[t]{4}{*}{ Broiler breeders (36w) } & H7N9 LPAI & 2 & $0 / 5$ & 5.6 & $0 / 5$ & $>6$ & nd \\
\hline & & 4 & $2 / 5$ & & $0 / 5$ & & nd \\
\hline & & 6 & $2 / 5$ & & $0 / 5$ & & nd \\
\hline & - & sham & $0 / 5$ & - & $0 / 5$ & - & - \\
\hline \multirow[t]{3}{*}{ SPF White Leghorn (4w) } & H7N9 LPAI & 2 & $0 / 5$ & 4.3 & $0 / 5$ & $>6$ & $0 / 3$ \\
\hline & & 4 & $2 / 5$ & & $0 / 5$ & & $0 / 3$ \\
\hline & & 6 & $5 / 5$ & & $0 / 5$ & & $0 / 3$ \\
\hline \multirow[t]{4}{*}{ SPF White Leghorn (4w) } & H7N9 HPAI & 2 & $3 / 5$ & $<2$ & $3 / 5(2.3)$ & $<2$ & $0 / 3$ \\
\hline & & 4 & $5 / 5$ & & $5 / 5(\leq 2.4)$ & & $0 / 3$ \\
\hline & & 6 & $5 / 5$ & & $5 / 5(2.2)$ & & $1 / 3$ (dead) \\
\hline & - & sham & $0 / 5$ & - & $0 / 5$ & - & - \\
\hline
\end{tabular}

$\mathrm{BID}_{50}$ : mean bird infectious dose, $\mathrm{BLD}_{50}$ : mean bird lethal dose, MDT: mean death time in days, nd: not determined.

a Birds were considered infected if they shed virus and/or were positive for antibodies at $14 \mathrm{dpc}$.

b \#dead birds $\times$ dpc/total dead birds.

c Contact-exposed birds were considered infected if they died, shed virus, and/or were positive for antibodies at $14 \mathrm{dpc}$.

the intra-choanal route to 5 birds per dose. The inocula titers were subsequently verified by back titration in ECE as within $0.5 \log _{10}$ of the target titer for all groups. In addition, 5 sham-exposed birds from each bird type were inoculated with $0.1 \mathrm{~mL}$ of sterile allantoic fluid diluted 1:300 in BHI media. In SPF layer chickens, contact-exposure transmission was evaluated by adding 3 non-inoculated hatch-mates (contacts) to each dose group at 1 day post-challenge (dpc). Clinical signs were monitored daily. Oropharyngeal (OP) and cloacal (CL) swabs were collected from all birds at 2, 4, 7, and $10 \mathrm{dpc}$, placed in $1.5 \mathrm{~mL}$ of BHI with penicillin (2000 units $/ \mathrm{mL}$; Sigma Aldrich, St. Louis, MO, USA), gentamicin $(200 \mu \mathrm{g} /$ $\mathrm{mL}$; Sigma Aldrich) and amphotericin B $(5 \mu \mathrm{g} / \mathrm{mL}$; Sigma Aldrich), and stored at $-80{ }^{\circ} \mathrm{C}$ until use. Severely sick birds were euthanized and counted as dead for the next day in mean death time (MDT) calculations. At 14 $\mathrm{dpc}$, survivors were bled to evaluate seroconversion and euthanized.

\section{Pathogenesis}

To evaluate pathogenicity, 3 broiler breeders were challenged with $6 \log _{10} \mathrm{EID}_{50}$ of the H7N9 LPAI virus, $10 \mathrm{SPF}$ layer chickens were challenged with $6 \log _{10} \mathrm{EID}_{50}$ of the H7N9 LPAI virus, and 10 SPF layer chickens were challenged with $6 \log _{10} \mathrm{EID}_{50}$ of the H7N9 HPAI virus. At 2 dpc (for HPAI group) or $3 \mathrm{dpc}$ (for LPAI groups), $2 \mathrm{SPF}$ layers and 3 broiler breeders per group were euthanized for necropsy to examine for gross lesions and collect tissues for microscopic evaluation. Two sham-exposed birds per group were also euthanized and necropsied as control birds. A full set of tissues was collected from each bird and fixed in 10\% neutral buffered formalin solution (Thermo Fisher Scientific, Waltham, MA, USA), paraffin-embedded, sectioned, and stained with hematoxylin-and-eosin (HE). Duplicate sections were stained by immunohistochemistry (IHC) to visualize the distribution of influenza virus antigen in individual tissues using a mouse-derived monoclonal antibody (P13C11, developed at SEPRL) specific for type A influenza virus nucleoprotein [27]. Lung, spleen, heart, muscle, and brain (SPF layer chickens and broiler breeders), as well as portions of each section of the reproductive tract, i.e. ovary, infundibulum, magnum, isthmus, and shell gland (broiler breeders) were also collected and frozen at $-80{ }^{\circ} \mathrm{C}$ for subsequent virus detection.

\section{Viral RNA quantification in swabs and tissues}

Swabs and tissues were processed for quantitative realtime RT-PCR (qRRT-PCR) to determine total viral RNA. Virus titers in tissue samples were determined after weighing, homogenizing, and diluting tissues in BHI to a $10 \%(\mathrm{wt} / \mathrm{vol})$ concentration. Total RNA was extracted from tissues using Trizol LS reagent (Invitrogen, Carlsbad, CA, USA) and the Qiagen RNeasy Mini Kit (Qiagen Corp, Valencia, CA, USA) was used to recover RNA from the aqueous phase. Equal amounts of RNA extracted from the tissue samples were used in the qRRT-PCR assay $(50 \mathrm{ng} / \mu \mathrm{L})$. Total RNA was extracted from swabs using MagMAX ${ }^{\mathrm{TM}}-96$ AI/ND Viral RNA Isolation $\mathrm{Kit}^{\circledR}$ (Ambion, Inc., Waltham, MA, USA). The resulting tissue and swab viral RNA extracts were quantified by one-step qRRT-PCR targeting the influenza matrix gene [28] using 7500 FAST Real-time PCR System (Applied Biosystems, 
Foster City, CA, USA). For virus quantification, standard curves were established with RNA from dilutions of the egg passage 2 of the challenge viruses (no significant differences in matrix detection were observed between egg passages 1 and 2). Results were reported as $\mathrm{EID}_{50} / \mathrm{mL}$ or $\mathrm{EID}_{50} / \mathrm{g}$ equivalents. The lower detection limit for H7N9 LPAI virus was $0.9 \log _{10} \mathrm{EID}_{50} / \mathrm{mL}\left(1.9 \log _{10} \mathrm{EID}_{50} / \mathrm{g}\right.$ for tissue samples). The lower detection limit for H7N9 HPAI virus was $1.5 \log _{10} \mathrm{EID}_{50} / \mathrm{mL}\left(2.5 \log _{10} \mathrm{EID}_{50} / \mathrm{g}\right.$ for tissue samples). For statistical purposes, qRRT-PCR negative swabs were given the value of $0.1 \log _{10}$ below the corresponding qRRT-PCR test limit of detection. Significant difference for mean viral titers between groups was analyzed using Mann-Whitney test (GraphPad Prism ${ }^{\text {TM }}$ Version 5 software). A $p$-value of $<0.05$ was considered to be significant.

\section{Serology}

Sera samples were tested by HI assays [29] against challenge virus antigens [30]. Titers were calculated as the reciprocal of the last $\mathrm{HI}$ positive serum dilution and samples with HI titers of $8\left(2^{3}\right)$ or below were considered negative. Sera samples were also tested using a commercial ELISA (AI Multi-S-Screen, IDEXX, Westbrook, ME, USA).

\section{Results \\ Infectivity, transmission, and pathogenicity of the H7N9 LPAl virus in broiler breeders}

Based on serology and viral RNA detection in swabs, no broiler breeders were infected in the lowest dose group, while $40 \%$ were infected in the medium and high dose groups; the resulting $\mathrm{BID}_{50}$ was $5.6 \log _{10} \mathrm{EID}_{50}$ (Table 1 ). Virus was only detected at $2 \mathrm{dpc}$ in OP swabs of $2 / 5$ chickens inoculated with the medium dose, and up to 7 $\mathrm{dpc}$ in OP swabs of $1 / 5$ chickens inoculated with the high dose (Figure 1A). Virus in CL swabs was not detected or detected at minimal titers in the medium and high dose groups. The LPAI virus did not cause clinical disease in infected broiler breeders, and no gross lesions or histopathological findings were observed in the 3 chickens necropsied at $3 \mathrm{dpc}$ from the high dose group. In addition, no virus titers were detected by qRRT-PCR in any of the tissues tested (Table 2).

\section{Infectivity, transmission, and pathogenicity of the H7N9 LPAI virus in SPF layer chickens}

Based on serology and virus RNA detection in swabs, no SPF layers were infected in the lowest dose group, while $40 \%$ and $100 \%$ were infected in the medium and high dose groups, respectively; the resulting $\mathrm{BID}_{50}$ was 4.3 $\log _{10}$ EID $_{50}$ (Table 1 ). Virus was only detected at 2 and $4 \mathrm{dpc}$ in OP swabs of $3 / 5$ chickens inoculated with the highest dose, while virus in CL swabs was not detected in any dose group (Figure 1B). No contact chickens were infected in any of the dose groups based on lack of seroconversion and lack of virus detection in swabs (Table 1). The LPAI virus did not cause clinical disease in infected SPF layers, and no gross lesions were observed in the 2 chickens necropsied at $3 \mathrm{dpc}$ from the pathogenesis group. Histologically, mild lymphocytic rhinitis and tracheitis were observed in both chickens examined and was associated with rare AI virus antigen staining in epithelial cells and infiltrating macrophages of the nasal cavity turbinates and trachea. No virus titers were detected by qRRT-PCR in tissues of the 2 necropsied birds (Table 2).

\section{Infectivity, transmission, and pathogenicity of the H7N9 HPAl virus in SPF layer chickens}

Sixty percent mortality was observed in the lowest dose group, while $100 \%$ of the birds died in the medium and high dose groups (MDT 2.3 days); the resulting $\mathrm{BLD}_{50}$ was $<2 \log _{10} \operatorname{EID}_{50}$ (Table 1). Survivors lacked clinical signs, virus shedding, and seroconversion, and thus were considered uninfected. In contrast, most birds that became infected and died or were euthanized shed a high quantity of virus prior to death, both via the oropharynx and the cloaca (Figure $1 \mathrm{C}$ ). Also, virus titers shed via the OP route at peak shedding day were significantly higher in H7N9 HPAI group (mean $4.1 \log _{10}$ EID $_{50}$ ) than H7N9 LPAI groups (means 1.3 and $1.7 \log _{10}$ EID $_{50}$ for broiler breeders and SPF layers, respectively) (data not shown). The resulting $\mathrm{BID}_{50}$ was $<2 \log _{10} \mathrm{EID}_{50}$ (Table 1 ). One contact bird of the high dose group died at $4 \mathrm{dpc}$. The majority of birds that died did so by $2 \mathrm{dpc}$ without showing clinical signs (i.e. peracute disease). Birds that took a day or more to die were euthanized because of severe clinical signs including swollen heads, ruffled feathers, conjunctivitis, lethargy, anorexia, prostration, and cyanotic combs and wattles. The two necropsied birds had empty intestines and were dehydrated. Petechial hemorrhages were observed in the eyelid of one bird. Similar type and severity of histological lesions were observed in both birds examined (see Additional file 1). Moderate to severe, multifocal necrosis was present in the parenchymal cells of many tissues but especially in lung, heart, spleen, and adrenal gland, in some cases accompanied with mild to severe inflammation. Staining for viral antigen was present in areas of necrosis and infiltrating mononuclear cells in many tissues including lymphoid tissues, lung, brain, liver, adrenal gland, and spleen. Staining was also present in parenchymal cells of some organs, including cardiac myocytes, Kupffer cells, hepatocytes, microglial cells and neurons, epithelium of 

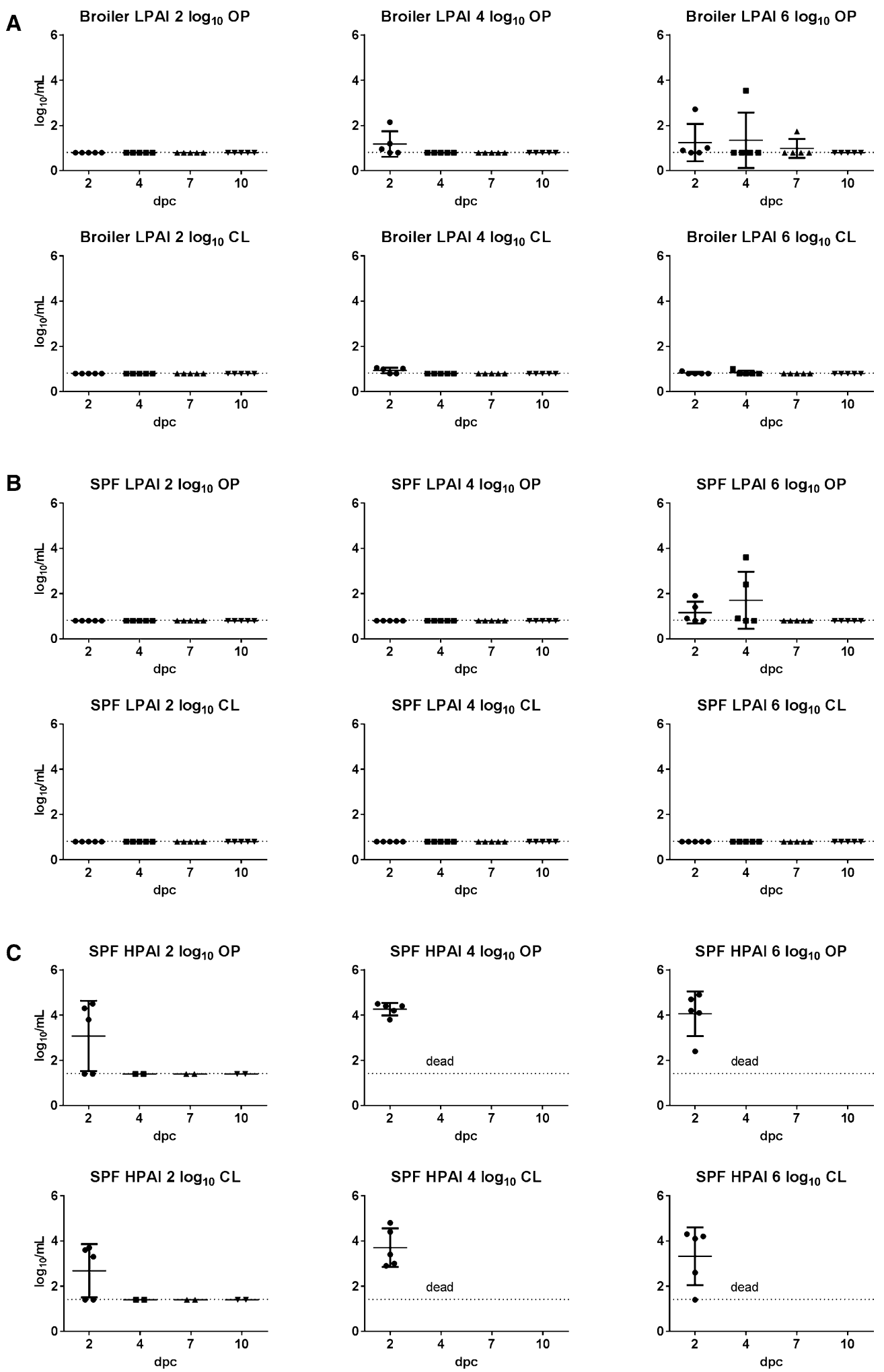

Figure 1 Scatter plot of oropharyngeal (OP) and cloacal (CL) virus shedding. A Broiler breeders inoculated with H7N9 LPAI virus. B SPF White Leghorn chickens inoculated with H7N9 LPAI virus. C SPF White Leghorn chickens inoculated with H7N9 HPAI virus. Virus detection by aRRT-PCR. Shedding titers are expressed as $\log _{10}$ with error bars. For statistical purposes, negative samples were given the value of $0.1 \log _{10}$ below the qRRT-PCR test limit of detection $\left(0.8 \log _{10} \mathrm{EID}_{50} / \mathrm{mL}\right.$ for H7N9 LPAI virus and $1.4 \log _{10}$ EID ${ }_{50} / \mathrm{mL}$ for H7N9 HPAI virus). 
Table 2 Virus detection and titers in tissues from broiler breeders and SPF White Leghorn chickens inoculated with Tennessee 2017 H7N9 LPAI or HPAI viruses

\begin{tabular}{|c|c|c|c|c|c|c|c|c|}
\hline \multirow[t]{2}{*}{ Bird type (age) } & \multirow[t]{2}{*}{ Pathotype } & \multirow{2}{*}{$\begin{array}{l}\text { Day post- } \\
\text { challenge }\end{array}$} & \multicolumn{6}{|c|}{ No. with virus detected/total (titer as $\left.\log _{10} \mathrm{EID}_{50} / \mathrm{g}\right)^{\mathrm{d}}$} \\
\hline & & & Lung & Spleen & Heart & Brain & Muscle & $\begin{array}{l}\text { Reproductive } \\
\text { tract }^{\text {e }}\end{array}$ \\
\hline Broiler breeders $(36 w)^{a}$ & LP & 3 & $0 / 3$ & $0 / 3$ & $0 / 3$ & $0 / 3$ & $0 / 3$ & $0 / 3$ \\
\hline SPF White Leghorn $(4 w)^{b}$ & $L P$ & 3 & $0 / 2$ & $0 / 2$ & $0 / 2$ & $0 / 2$ & $0 / 2$ & nd \\
\hline SPF White Leghorn $(4 w)^{c}$ & $\mathrm{HP}$ & 2 & $2 / 2(7.2 \pm 0.3)$ & $2 / 2(7.3 \pm 0.2)$ & $2 / 2(8.3 \pm 0.3)$ & $2 / 2(7.0 \pm 0.6)$ & $2 / 2(7.5 \pm 0.4)$ & nd \\
\hline
\end{tabular}

Virus detection by qRRT-PCR.

nd: not determined.

a Tissues from 3 broiler breeders necropsied at $3 \mathrm{dpc}$. The threshold of detection in tissues was $1.9 \log _{10} \mathrm{EID}_{50} / \mathrm{g}$ for H7N9 LPAI virus.

${ }^{b}$ Tissues from 2 SPF layer birds necropsied at $3 \mathrm{dpc}$. The threshold of detection in tissues was $1.9 \log _{10} \mathrm{EID}_{50} / \mathrm{g}$ for H7N9 LPAI virus.

c Tissues from 2 SPF layer birds necropsied at $2 \mathrm{dpc}$. The threshold of detection in tissues was $2.5 \log _{10} \mathrm{EID}_{50} / \mathrm{g}$ for H7N9 HPAl virus.

d Mean titer \pm SD.

e All sections of the reproductive tract were tested: ovary, infundibulum, magnum, isthmus, and shell gland.

air capillaries in the lung, kidney tubular epithelial and glomerular cells, and feather follicle epithelial cells. Viral antigen was commonly detected in vascular endothelial cells in the nasal cavity, trachea, eyelid, and comb, while in all other tissues viral antigen was only detected in a few, individual vascular endothelial cells. High virus titers (7.0-8.3 $\left.\log _{10} \mathrm{EID}_{50} / \mathrm{g}\right)$ were detected by qRRT-PCR in brain, spleen, heart, lung, and muscle of both necropsied birds (Table 2).

\section{Discussion}

In this study, neither broiler breeders nor SPF layer birds exhibited clinical signs or death when experimentally infected with the Tennessee 2017 H7N9 LPAI isolate. This is consistent with a report by Spackman et al. [31] where chickens showed high seroconversion rates (70-100\%) to all tested North American H7 LPAI viruses $(n=12)$ following experimental inoculation studies, but exhibited sub-clinical to mild diseases. However, severe clinical disease has occurred with some LPAI viruses in the field when accompanied by concomitant factors [4]. In fact, in the currently investigated outbreak, some H7N9 LPAI virus-affected commercial broiler breeder barns had drops in egg production for a short period of time and increased mortality [9]. Although LPAI viruses are generally restricted to the respiratory and gastrointestinal tracts when not inoculated by intravenous or intramuscular injection [32,33], some LPAI viruses have been isolated from a limited number of other tissues including the pancreas, kidneys, and oviduct of intranasally inoculated chickens $[34,35]$, and from the kidneys, ovary, and oviduct of intratracheally inoculated birds $[4,36]$. In our study, no LPAI virus was detected in the reproductive tract or other tissues of the broiler breeders, indicating that other factors, infectious and non-infectious, might aggravate the clinical presentation of LPAI virus under field conditions.

The estimated $\mathrm{BID}_{50}$ for the LPAI isolate was $4.3 \log _{10}$ EID $_{50}$ for SPF layer chickens, versus $5.6 \log _{10}$ EID $_{50}$ for broiler breeders. While these BID $_{50}$ were lower than BID $_{50}$ for non-poultry origin North American H7 LPAI viruses (6.2-6.9 $\log _{10} E \mathrm{EID}_{50}$ ) [37], no contact-exposed SPF layer birds were infected in our study, suggesting insufficient chicken adaptation of Tennessee H7N9 LPAI viruses for sustained transmission. Although transmission was not evaluated in broiler breeders, similar virus shedding dynamics between both bird types and higher $\mathrm{BID}_{50}$ for broiler breeders suggest that transmission would have been unlikely in the broiler breeder groups. It is worth noting that neither broiler breeders nor SPF layers shed LPAI virus by the CL route, which lack of can critically hinder virus transmission among birds [38]. Field conditions, including associated secondary infections, immunosuppression, or adverse environmental conditions, might lower the minimum AI virus exposure dose needed to infect commercial broiler breeders, thus emphasizing the importance of good biosecurity and management practices in controlling AI virus, as previously suggested by our group [21]. As aforementioned, the absence of affected layer premises could be due to a low number of layer farms compared to broiler breeder farms in the affected region or failure to introduce AI virus onto the farms due to management factors [9]. Therefore, the two systems vary in conditions that could impact virus exposure and maintenance, as well as host susceptibility and detection [9].

The H7N9 HPAI isolate had better infectivity and transmissibility in SPF chickens than its LPAI precursor. The $\mathrm{BID}_{50}$ for the HPAI isolate was more than 2 logs lower $\left(<2 \log _{10} \mathrm{EID}_{50}\right)$ than the LPAI isolate $\left(4.3 \log _{10}\right.$ 
EID $_{50}$ ). In addition, H7N9 HPAI-infected groups showed replication and shedding pattern differences compared to LPAI-infected groups: significant higher virus shedding titers, higher (although not significant) number of birds shedding, and gastrointestinal replication detected via $C L$ swabs in addition to respiratory tract replication detected via OP swabs. Consistent with our findings, higher infectivity, lethality, and transmissibility of the HPAI phenotype were demonstrated in chickens for the H7N8 (Indiana, 2016) and H5N2 HPAI (Pennsylvania, 1983) viruses compared to their LPAI phenotype precursor $[39,40]$. Collectively, these differences likely contributed to an increased efficiency of HPAI viral replication and contamination in the environment, with subsequent better transmission to HPAI virus contact-exposed birds. Transmission efficiency in our experimental conditions is likely underestimated due to an artifact of our housing (isolators with high rates of airflow and grate floors) as discussed previously [40] and lack of concomitant management factors that might be encountered in commercial farms which can increase environmental contamination, individual bird exposure, and inter-farm transmission.

Before the H7N9 outbreak in Tennessee in 2017, the most recent H7 HPAI outbreak in USA occurred in 2016, affecting turkeys in Indiana [25]. Both the H7N9 Tennessee (2017) and H7N8 Indiana (2016) events were identified when a LPAI virus mutated to HPAI virus, and samples were collected in response to clinical signs observed in the birds [9]. The distribution of cases and the presence of antibody-positive flocks for the H7N9 2017 outbreak suggest that detection occurred later during the course of infection as compared to the H7N8 2016 outbreak, where infection was detected shortly after virus introduction based upon virus detection in turkeys in both HPAI and LPAI virus-affected barns [9]. During both the H7N9 2017 and the H7N8 2016 events, HPAI virus-infected flocks were rapidly detected, quarantined, and depopulated [9], leading to single-farm spread in H7N9 2017 outbreak and no farm-to-farm spread in H7N8 2016 outbreak [40]. Such prompt detection resulted in outbreaks of short duration by limiting environmental contamination and potential for virus spread to susceptible flocks regardless of the infectivity of the virus and the titers of virus shed [40]. The H7N9 LPAI and HPAI isolates tested here had similar $\mathrm{BID}_{50}$ in SPF layer chickens to the H7N8 virus (Indiana, 2016) [40]. Regarding genetic relatedness, the H7N9 2017 and H7N8 2016 viruses share five of eight genes (PB2, PB1, HA, NP, MP) but are clearly different in the other three genes (PA, NA, NS) [9]. All H7N9 viruses isolated from the 2017 outbreak shared high levels of nucleotide identity (>99.2-99.7\%) across all 8 gene segments except for the insertion at the HA cleavage site in the HPAI viruses [8]. However, based on genetic analysis, more than one H7N9 virus introduction occurred from wild birds into commercial broiler breeders and backyard poultry, with the LPAI virus circulating undetected in poultry in the USA southeast region for 1-3 months [8]. Consequently, differences in infectivity, transmission, and pathogenicity among different LPAI virus isolates from this outbreak might exist.

In conclusion, we observed inadequate or sub-optimal adaptation for sustained transmission with the H7N9 LPAI isolate in both broiler breeders and SPF layer birds. These findings suggest that not only the bird genetic background but also other factors including the birds immunological status, field production conditions, biosecurity, and management practices are involved in the epidemiology of the outbreak which affected mainly broiler breeder commercial premises [8,9]. In addition, higher susceptibility and transmissibility of the H7N9 HPAI virus are features of the HP phenotype that could help in the spread of HPAI viruses during outbreaks.

\section{Additional file}

\section{Additional file 1. Microscopic lesions and viral antigen distribution in tissues from chickens inoculated with H7N9 HPAI virus. Four week-old specific pathogen free (SPF) White Leghorn chickens were challenged with A/chicken/Tennessee/17-007147-2/2017 H7N9 HPAI virus and sampled at $2 \mathrm{dpc}$.}

\section{Abbreviations}

Al: avian influenza; APHIS: Animal and Plant Health Inspection Service; ARS: Agricultural Research Service; $\mathrm{BH}$ : brain heart infusion; $\mathrm{BID}_{50}$ : mean bird infectious dose; $B_{5 D}$ : mean bird lethal dose; BSL-3E: biosecurity level-3 enhanced; $\mathrm{CL}$ : cloacal; dpc: day post-challenge; ECE: embryonating chickens eggs; EID $_{50}$ : mean egg infectious dose; HA: hemagglutinin; HE: hematoxylin-and-eosin; $\mathrm{HI}$ : hemagglutinin inhibition; HP: highly pathogenic; IHC: immunohistochemistry; LP: low pathogenic; MDT: mean death time; nd: not determined; OP: oropharyngeal; qRRT-PCR: quantitative real-time RT-PCR; SPF: specific pathogen free; USDA: United States Department of Agriculture; USNPRC: U.S. National Poultry Research Center.

\section{Competing interests}

The authors declare that they have no competing interests.

\section{Authors' contributions}

MPJ and DES conceived this project. KB, DHL, MFC, DS, and MPJ conducted the animal experiments and sample processing. KB and DS analyzed the data. $\mathrm{KB}$ and MPJ drafted the manuscript. All authors read and approved the final manuscript.

\section{Acknowledgements}

The authors would like to thank John Smith and Sarah Tilley from Fieldale Farms Corp., Baldwin, GA for providing the broiler breeders utilized in this study. The authors gratefully acknowledge Lindsay Killmaster, Nikolai Lee, Roger Brock, Keith Crawford, and Gerald Damron for their excellent technical assistance.

Funding

This research was supported by the ARS Project 6040-32000-066-00D, CRIP (Center of Research in Influenza Pathogenesis) an NIAID funded Center 
of Excellence in Influenza Research and Surveillance (CEIRS, contract HHSN272201400008C), and ARS/APHIS interagency agreement 60-6040-6007. Its contents are solely the responsibility of the authors and do not necessarily represent the official views of the USDA or NIH. Mention of trade names or commercial products in this publication is solely for the purpose of providing specific information and does not imply recommendation or endorsement by the USDA. USDA is an equal opportunity provider and employer.

\section{Publisher's Note}

Springer Nature remains neutral with regard to jurisdictional claims in published maps and institutional affiliations.

Received: 25 June 2018 Accepted: 20 July 2018

Published online: 29 August 2018

\section{References}

1. Slemons RD, Johnson DC, Osborn JS, Hayes F (1974) Type-A influenza viruses isolated from wild free-flying ducks in California. Avian Dis 18:119-124

2. Kawaoka Y, Chambers TM, Sladen WL, Webster RG (1988) Is the gene pool of influenza viruses in shorebirds and gulls different from that in wild ducks? Virology 163:247-250

3. Alexander DJ (2000) A review of avian influenza in different bird species. Vet Microbiol 74:3-13

4. Spickler AR, Trampel DW, Roth JA (2008) The onset of virus shedding and clinical signs in chickens infected with high-pathogenicity and lowpathogenicity avian influenza viruses. Avian Pathol 37:555-577

5. Swayne DE, Pantin-Jackwood MJ (2008) Pathobiology of avian influenza virus infections in birds and mammals. In: Swayne DE (ed) Avian influenza. Blackwell Publishing, Ames

6. World Organisation for Animal Health (OIE) (2017) Cumulative number of confirmed human cases of avian influenza $\mathrm{A}(\mathrm{H} 5 \mathrm{~N} 1)$ reported to $\mathrm{WHO}$. http://www.who.int/influenza/human_animal_interface/H5N1_cumul ative_table_archives/en/. Accessed 1 Aug 2018

7. Sims LD, Weaver J, Swayne DE (2016) Epidemiology of avian influenza in agricultural and other man-made systems. In: Swayne DE (ed) Animal influenza. Blackwell Publishing, Ames

8. Lee DH, Torchetti MK, Killian ML, Berhane Y, Swayne DE (2017) Highly pathogenic avian influenza A(H7N9) virus, Tennessee, USA, March 2017 Emerg Infect Dis. https://doi.org/10.3201/eid2311.171013

9. United States Department of Agriculture, Animal and Plant Health Inspection Service (2017) Epidemiologic and other analyses of HPAI/LPAI affected poultry flocks: June 26, 2017 Report. USDA:APHIS:VS:STAS:Center for Epidemiology and Animal Health Doc \#391.0317 V2

10. Koenen ME, Boonstra-Blom AG, Jeurissen SH (2002) Immunological differences between layer- and broiler-type chickens. Vet Immunol Immunopathol 89:47-56

11. Zheng Q, Zhang Y, Chen Y, Yang N, Wang XJ, Zhu D (2009) Systematic identification of genes involved in divergent skeletal muscle growth rates of broiler and layer chickens. BMC Genomics 10:87

12. Druyan S (2010) The effects of genetic line (broilers vs. layers) on embryo development. Poult Sci 89:1457-1467

13. Swayne DE, Radin MJ, Hoepf TM, Slemons RD (1994) Acute renal failure as the cause of death in chickens following intravenous inoculation with avian influenza virus A/chicken/Alabama/7395/75 (H4N8). Avian Dis 38:151-157

14. Ko JH, Jin HK, Asano A, Takada A, Ninomiya A, Kida H, Hokiyama H, Ohara M, Tsuzuki M, Nishibori M, Mizutani M, Watanabe T (2002) Polymorphisms and the differential antiviral activity of the chicken Mx gene. Genome Res 12:595-601

15. Henzler DJ, Kradel DC, Davison S, Ziegler AF, Singletary D, DeBok P, Castro AE, Lu H, Eckroade R, Swayne D, Lagoda W, Schmucker B, Nesselrodt A (2003) Epidemiology, production losses, and control measures associated with an outbreak of avian influenza subtype H7N2 in Pennsylvania (1996-98). Avian Dis 47:1022-1036

16. Kalaya B, Sawat T, Neramit S, Voravit V, Voravit S, Tadayoshi M (2006) Influence of MHC class II haplotypes on avian influenza traits in Thai indigenous chicken. J Poult Sci 43:120-125
17. Balkissoon D, Staines K, McCauley J, Wood J, Young J, Kaufman J, Butter C (2007) Low frequency of the Mx allele for viral resistance predates recent intensive selection in domestic chickens. Immunogenetics 59:687-691

18. Sironi L, Williams JL, Moreno-Martin AM, Ramelli P, Stella A, Jianlin H, Weigend S, Lombardi G, Cordioli P, Mariani P (2008) Susceptibility of different chicken lines to H7N1 highly pathogenic avian influenza virus and the role of Mx gene polymorphism coding amino acid position 631. Virology 380:152-156

19. Hunt HD, Jadhao S, Swayne DE (2010) Major histocompatibility complex and background genes in chickens influence susceptibility to high pathogenicity avian influenza virus. Avian Dis 54(1 Suppl):572-575

20. Matsuu A, Kobayashi T, Patchimasiri T, Shiina T, Suzuki S, Chaichoune K, Ratanakorn P, Hiromoto Y, Abe H, Parchariyanon S, Saito T (2016) Pathogenicity of genetically similar, H5N1 highly pathogenic avian influenza virus strains in chicken and the differences in sensitivity among different chicken breeds. PLoS One 11:e0153649

21. Bertran K, Lee DH, Balzli C, Pantin-Jackwood MJ, Spackman E, Swayne DE (2016) Age is not a determinant factor in susceptibility of broilers to H5N2 clade 2.3.4.4 high pathogenicity avian influenza virus. Vet Res 47:116

22. DeJesus E, Costa-Hurtado M, Smith D, Lee DH, Spackman E, Kapczynski DR, Torchetti MK, Killian ML, Suarez DL, Swayne DE, Pantin-Jackwood MJ (2016) Changes in adaptation of H5N2 highly pathogenic avian influenza H5 clade 2.3.4.4 viruses in chickens and mallards. Virology 499:52-64

23. Spackman E, Pantin-Jackwood MJ, Kapczynski DR, Swayne DE, Suarez DL (2016) H5N2 highly pathogenic avian influenza viruses from the US 2014-2015 outbreak have an unusually long pre-clinical period in turkeys. BMC Vet Res 12:260

24. United States Department of Agriculture, Animal and Plant Health Inspection Service (2015) Highly pathogenic avian influenza infected premises 2014-2015. https://www.aphis.usda.gov/animal_health/anima I_dis_spec/poultry/downloads/hpai-positive-premises-2014-2015.pdf. Accessed 1 Aug 2018

25. Killian ML, Kim-Torchetti M, Hines N, Yingst S, DeLiberto T, Lee DH (2016) Outbreak of H7N8 low pathogenic avian influenza in commercial turkeys with spontaneous mutation to highly pathogenic avian influenza. Genome Announc 16:e00457-16

26. Spackman E, Killian ML (2014) Avian influenza virus isolation, propagation, and titration in embryonated chicken eggs. Methods Mol Biol 1161:125-140

27. Pantin-Jackwood MJ (2014) Immunohistochemical staining of influenza virus in tissues. Methods Mol Biol 1161:51-58

28. Spackman E, Senne DA, Myers TJ, Bulaga LL, Garber LP, Perdue ML, Lohman K, Daum LT, Suarez DL (2002) Development of a real-time reverse transcriptase PCR assay for type A influenza virus and the avian $\mathrm{H} 5$ and H7 hemagglutinin subtypes. J Clin Microbiol 40:3256-3260

29. Pedersen JC (2014) Hemagglutination-inhibition assay for influenza virus subtype identification and the detection and quantitation of serum antibodies to influenza virus. In: Spackman E (ed) Animal influenza virus. Springer, New York

30. Abbas MA, Spackman E, Fouchier R, Smith D, Ahmed Z, Siddique N, Sarmento L, Naeem K, McKinley ET, Hameed A, Rehmani S, Swayne DE (2011) H7 avian influenza virus vaccines protect chickens against challenge with antigenically diverse isolates. Vaccine 29:7424-7429

31. Spackman E, Gelb J Jr, Preskenis LA, Ladman BS, Pope CR, Pantin-Jackwood MJ, McKinley ET (2010) The pathogenesis of low pathogenicity H7 avian influenza viruses in chickens, ducks and turkeys. Virol J 7:331

32. Swayne DE, Beck JR (2005) Experimental study to determine if low-pathogenicity and high-pathogenicity avian influenza viruses can be present in chicken breast and thigh meat following intranasal virus inoculation. Avian Dis 49:81-85

33. Zepeda C, Salman MD (2007) Assessing the probability of the presence of low pathogenicity avian influenza virus in exported chicken meat. Avian Dis 51(1 Suppl):344-351

34. Lu H, Castro AE (2004) Evaluation of the infectivity, length of infection, and immune response of a low-pathogenicity H7N2 avian influenza virus in specific-pathogen-free chickens. Avian Dis 48:263-270

35. Okamatsu M, Saito T, Yamamoto Y, Mase M, Tsuduku S, Nakamura K, Tsukamoto K, Yamaguchi S (2007) Low pathogenicity H5N2 avian influenza outbreak in Japan during the 2005-2006. Vet Microbiol 124:35-46 
36. Shalaby AA, Slemons RD, Swayne DE (1994) Pathological studies of A/ chicken/Alabama/7395/75 (H4N8) influenza virus in specific-pathogenfree laying hens. Avian Dis 38:22-32

37. Swayne DE, Slemons RD (2008) Using mean infectious dose of high- and low-pathogenicity avian influenza viruses originating from wild duck and poultry as one measure of infectivity and adaptation to poultry. Avian Dis 52:455-460

38. Ruiz-Hernandez R, Mwangi W, Peroval M, Sadeyen JR, Ascough S, Balkissoon D, Staines K, Boyd A, McCauley J, Smith A, Butter C (2016)
Host genetics determine susceptibility to avian influenza infection and transmission dynamics. Sci Rep 6:26787

39. van der Goot JA, de Jong MC, Koch G, Van Boven M (2003) Comparison of the transmission characteristics of low and high pathogenicity avian influenza A virus (H5N2). Epidemiol Infect 131:1003-1013

40. Pantin-Jackwood MJ, Stephens CB, Bertran K, Swayne DE, Spackman E (2017) The pathogenesis of H7N8 low and highly pathogenic avian influenza viruses from the United States 2016 outbreak in chickens, turkeys and mallards. PLoS One 12:e0177265
Ready to submit your research? Choose BMC and benefit from:

- fast, convenient online submission

- thorough peer review by experienced researchers in your field

- rapid publication on acceptance

- support for research data, including large and complex data types

- gold Open Access which fosters wider collaboration and increased citations

- maximum visibility for your research: over $100 \mathrm{M}$ website views per year

At BMC, research is always in progress.

Learn more biomedcentral.com/submissions 